\title{
Can a dam type of an alpine lake be derived from lake geometry? A negative result
}

\author{
Adam EMMER 13* i https://orcid.org/oooo-0002-8268-99oX; Me-mail: adam.emmer@uni-graz.at; aemmer@seznam.cz \\ Vojtěch CUŘíN2,3 Đi https://orcid.org/oooo-0oo2-3975-9263; e-mail: curin@fzp.czu.cz \\ ${ }^{*}$ Corresponding author \\ 1 University of Graz, Institute of Geography and Regional Science, Cascade|The Mountain Processes and Mountain Hazards \\ Group, Graz 8010, Austria \\ 2 Czech University of Life Sciences Prague, Faculty of Environmental Sciences, Prague 1650o, Czechia \\ 3 Czech Academy of Sciences, Global Change Research Institute, Brno 6030o, Czechia
}

Citation: Emmer A, Cuřín V (2021) Can a dam type of an alpine lake be derived from lake geometry? A negative result. Journal of Mountain Science 18(3). https://doi.org/10.1007/s11629-020-6003-9

(C) The Author(s) 2021.

\begin{abstract}
Glacial lake outburst floods (GLOFs) represent one of the most serious hazard and risk in deglaciating high mountain regions worldwide and the need for GLOF hazard and risk assessment is apparent. As a consequence, numerous region- and nation-wide GLOF assessment studies have been published recently. These studies cover large areas and consider hundreds to thousands of lakes, prioritizing the hazard posed by them. Clearly, certain simplification is required for executing such studies, often resulting in neglecting qualitative characteristics which would need manual assignment. Different lake dam types (e.g., bedrock-dammed, moraine-dammed) are often not distinguished, despite they control GLOF mechanism (dam overtopping / dam breach) and thus GLOF magnitude. In this study, we explore the potential of easily measurable quantitative characteristics and four ratios to approximate the lake dam type. Our dataset of 851 lakes of the Cordillera Blanca suggests that while variances and means of these characteristics of individual lake types differ significantly ( $F$-test, $t$-test), value distribution of different geometrical properties can't be used for the originally proposed purpose along the spectra. The only promising results are obtained for extreme
\end{abstract}

Received: $28-\mathrm{Jan}-2020$

Revised: 22-Dec-2020

Accepted: 05-Feb-2021 values (selected bins) of the ratios. For instance, the low width to length ratio indicates likely morainedammed lake while the high value of ratio indicating round-shape of the lake indicates increased likelihood of bedrock-dammed lake. Overall, we report a negative result of our experiment since there are negligible differences of relative frequencies in most of the bins along the spectra.

Keywords: Alpine lake; High mountain lake; GLOFs; Glacial lake; Moraine-dammed; Bedrock-dammed; Negative result; Cordillera Blanca

\section{Introduction}

Glacial lake outburst floods (GLOFs) became well-studied phenomenon in past decades (Emmer 2018), being driven by concerns about potentially harmful socio-economic consequences (Carrivick and Tweed 2016) and substantial land-forming effects (Clague and Evans 2000; Emmer 2017; Cook et al. 2018). At the same time, changing climate conditions and glacier retreat in high mountainous regions are expected to further promote GLOF hazard (Harrison et al. 2018), although some studies do not clearly support this claim (Veh et al. 2019). Despite this 
recent progress in our understanding to the timing of GLOF occurrence on regional to global scale, identification of a specific GLOF-prone lake and estimating its hazard (i.e. the probability of GLOF occurrence with specified magnitude in a strict sense), is still a challenging task that is rarely addressed (e.g. GAPHAZ 2017).

Due to the stochastic occurrence in space and time, complex inter-linkages with various triggering processes and complicated predictability, GLOF hazard studies often do not estimate the probability, but susceptibility of lakes to produce GLOF, usually using a set of indicators, which are considered to indicate increased likelihood of GLOF occurrence (e.g. Huggel et al. 2004; Mergili and Schneider 2011; Emmer et al. 2016; Aggarwal et al. 2017; Kougkoulos et al. 2018; Yao et al. 2018). According to Emmer and Vilímek (2013), these can be grouped as: (i) characteristics of the lake (e.g., lake area, lake volume); (ii) characteristics of the dam (e.g., dam type, dam freeboard, dam geometry); (iii) characteristics of the lake surroundings (e.g., topographical potential for mass movements; potentially hazardous lakes located upstream). Some of these characteristics can be derived automatically from remotely sensed images (e.g. quantitative characteristics such as lake area), while others require manual expert assessment (e.g. qualitative characteristics such as dam type). Working on a regional- or national-wide scale, recently published GLOF susceptibility assessments often tend to be based on purely automatized procedures (e.g. Allen et al. 2019). Such approach has certain advantages (e.g. repeatability, reproducibility, objectivity, speed of the assessment procedure, large spatial coverage), but on the other hand, often naturally tends to simplify and neglect the characteristics which can't be derived automatically, such as the lake dam type. While several studies are devoted to (semi-)automatical identification and mapping of glacial lakes (e.g. Chen et al. 2012; Li and Sheng 2012; Zhang et al. 2019; Wangchuk and Bolch 2020; Shugar et al. 2020) or outburst flood paths (Veh et al. 2018), automatic assignment of lake dam types has not yet been explored.

The lake dam type (Fig.1) has been, however, identified to be a key characteristic controlling mechanism of water release (dam failure vs. dam overtopping) and GLOF magnitude. It was shown that GLOFs originating from dam failures have comparably larger volume of released water and might also have higher peak discharge comparing to GLOFs resulting from dam overtopping (see Emmer 2017). The formation of different lake dam types is associated with different processes and we assume that the shape of the lake is controlled by the interaction of forming process with default geomorphic, geologic, hydrologic and glaciologic setting. Keeping this in mind, the main objective of this study is to explore whether quantitative characteristics of alpine lakes can be used to derive likely dam type without the need for expert manual assessment, using Peruvian Cordillera Blanca as the

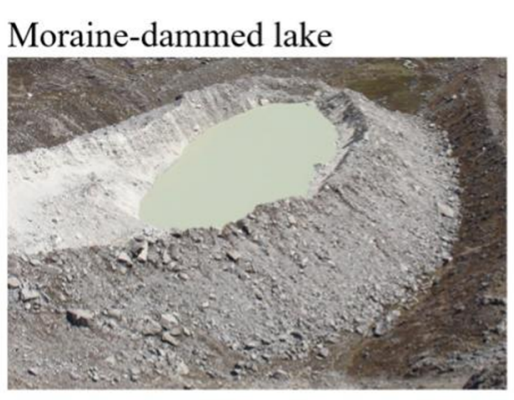

Not specified ('pampa') lake

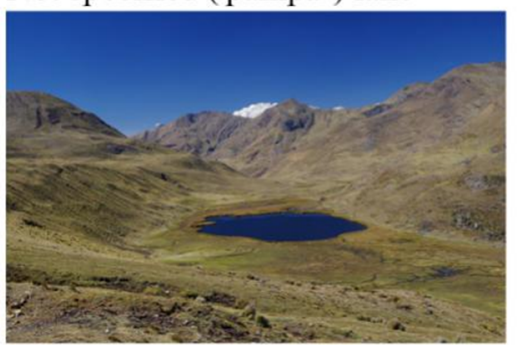

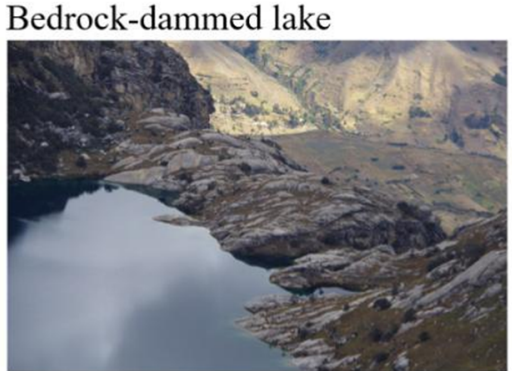

Ice-dammed (supraglacial) lake

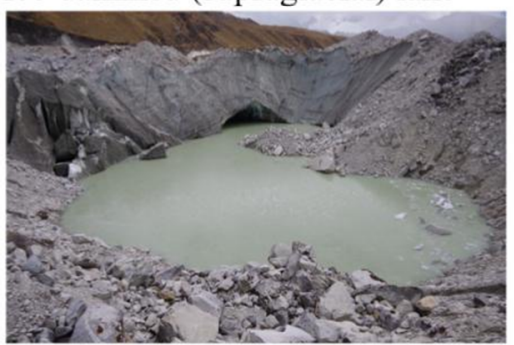

Combined dam

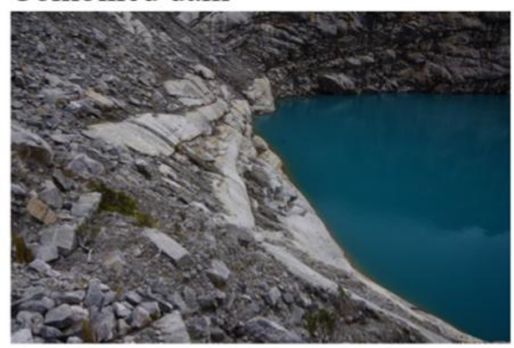

Landslide-dammed lake

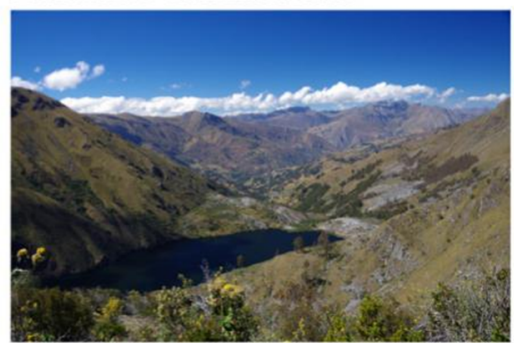

Fig.1 Examples of different lake dam types present in the study area of the Cordillera Blanca. 
study area. To this end, we explore geometrical characteristics of lakes and the relationship to different lake dam types.

\section{Materials and Methods}

The 2018 lake inventory of the Cordillera Blanca is used in this study (Emmer et al. 2020). Lake polygons were drawn manually in Google Earth Digital Globe environment over the latest satellite images CNES / Astrium / Airbus (2018 for the major part of the study area) with turned of terrain option (2D) and with the scale defined by the view height $\sim 2$ $\mathrm{km}$. Each lake in the inventory is described by several characteristics including the lake dam type. Six different lake dam types are distinguished (see Figure 1): (i) bedrock-dammed; (ii) moraine-dammed; (iii) combined dam; (iv) not specified lake; (v) landslidedammed; and (vi) ice-dammed (supraglacial). These dam types were assigned manually, based on a visual interpretation of high resolution satellite images available at Google Earth Digital Globe (Google Inc. 2015) and field validation.

Emmer et al. (2020) inventory consists of a total of 909 lakes. In this study, we only considered the lake dam types which are represented with 100 or more lakes in the database, i.e. dam types (i) - (iv), a total of 851 lakes. Four quantitative characteristics of lake polygons were then derived in ESRI ArcGIS v10.6 environment (see Table 1). These are: (i) Lake area (A); (ii) Lake perimeter $(P)$; (iii) Lake length $(L)$; and (iv) Lake width $(W)$. Four geometric ratios have been calculated from these characteristics to quantitatively describe the geometry of a lake polygon: (i) $W / L$ ratio; (ii) $P / A$ ratio; (iii) $A /(L \times W)$ ratio; and (iv) $2(\pi A)^{0.5} / P$ ratio (see schematic examples in Table 2).

Pairs of quantitative characteristics measured as well as ratios used are plotted and $\mathrm{R}^{2}$ values (squared value of Pearson corellation coefficient) are calculated to show possible interdependencies (see Appendix 1 and Appendix 2). It is shown that strong ( $R>0.6$ to $0.8)$ to very strong positive linear corellation $(R>0.8)$ exist between individual quantitative characteristics (Appendix 1) while no linear corellation $(R<0.4)$ exist between individual ratios used. The exception is a strong positive linear corellation $(R=0.709)$ between $2(\pi A)^{0.5} / P$ ratio and $A /(L \times W)$ ratio and weak positive linear corellation $(R=0.558)$ between $W / L$ ratio and $2(\pi A)^{0.5} / P$ ratio. Bin with 20 equal categories across the variability of individual ratios was used to create histograms.

Table 1 The list of quantitative characteristics and ratios used in this study.

\begin{tabular}{ll|l|}
\hline Quantitative characteristics & Description & Unit \\
\hline $\begin{array}{l}\text { Lake area }(A) \\
\text { Lake perimeter }(P)\end{array}$ & The area of the lake polygon & $\mathrm{m}^{2}$ \\
\hline $\begin{array}{l}\text { Lake length }(L) \\
\text { Lake width }(W)\end{array}$ & The length of the lake polygon perimeter & $\mathrm{m}$ \\
\hline $\begin{array}{l}\text { Geometric ratios } \\
W / L \text { ratio }\end{array}$ & The width of a minimum bounding rectangle & $\mathrm{m}$ \\
\hline$P / A$ ratio & Description & $\mathrm{m}$ \\
\hline $\mathrm{A} /(L \times W)$ ratio & The lower $W / L$ ratio indicates more prolonged shape of the lake polygon & Unit \\
$2(\pi A)^{0.5} / P$ ratio & The higher $P / A$ ratio indicates more rugged lake shoreline & - \\
\hline
\end{tabular}

Table 2 Schematic examples of geometric characteristic and ratios of three fictional lakes.

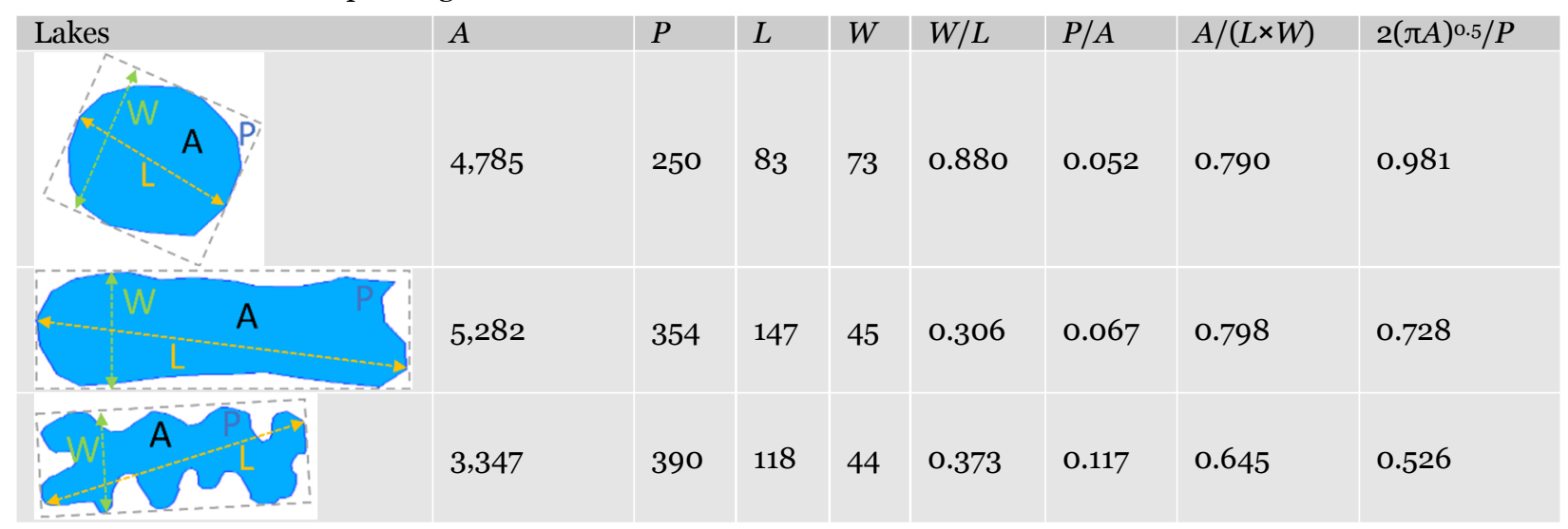


In order to quantify statistical difference between characteristics of two most common lake types (bedrock- and moraine-dammed lakes), we first employed $F$-test to test the hypothesis that the variances of two data series are equal or differ statistically, and $t$-test (two sample t-test assuming equal or unequal variances, based on the result of the $F$-test; two-tailed) to test whether means of these data series are equal or differ statistically.

\section{Results, Discussion and Conclusions}

\subsection{Statistics of the whole dataset}

Basic geometric characteristics of investigated lakes are shown in Table 3. The lake area A varies from $403 \mathrm{~m}^{2}$ to $1,725,186 \mathrm{~m}^{2}$ for the whole dataset. Mean area of different lake dam types varies from $13,386 \mathrm{~m}^{2}$ (not specified lakes) to $22,810 \mathrm{~m}^{2}$ (lakes with combined dams), 28,376 $\mathrm{m}^{2}$ (bedrock-dammed lakes), to $56,960 \mathrm{~m}^{2}$ (moraine-dammed lakes). Accordingly, moraine-dammed lakes also have higher average lake perimeter $P(769.2 \mathrm{~m})$. The $W / L$ ratio reaches similar values for different lake dam types, with average values ranging from 0.536 (moraine- dammed lakes) to 0.571 (not specified lakes).

\subsection{Statistical difference between bedrock- and moraine-dammed lakes}

Comparing the variances of geometric characteristics of bedrock- and moraine-dammed lakes (Table 4), it is seen that the $H_{0}$ (variances of geometric chatacteristics do not differ between bedrock- and moraine-dammed lakes) has been rejected for most of the characteristics and ratios, indicating that these characteristics differ significantly between bedrock- and moraine-dammed lakes. Similarly, statistically significant difference between means of geometric characteristics and ratios have been documented for most of the characteristics and ratios. Less distinct differences are observed when only the large lakes $\left(A>50,000 \mathrm{~m}^{2}\right)$ are considered (Table 5).

\subsection{Relationship between geometric ratios and lake dam types}

Different geomorphological processes lead to the formation of different lake dam types. While morphometric characteristics and ratios differ significantly (see Tables 3-5; section 3.2), our data

Table 3 Statistics of geometric characteristics of individual lake dam types.

\begin{tabular}{|c|c|c|c|c|c|}
\hline \multirow{2}{*}{\multicolumn{2}{|c|}{ Characteristic }} & \multicolumn{4}{|c|}{ Lake dam type (no. of lakes) } \\
\hline & & \multirow{2}{*}{$\begin{array}{l}\text { Moraine-dammed } \\
(315) \\
56,930(168,763)\end{array}$} & \multirow{2}{*}{$\begin{array}{l}\text { Bedrock-dammed } \\
(289) \\
28,376(78,227)\end{array}$} & \multirow{2}{*}{$\begin{array}{l}\text { Combined dam } \\
(142) \\
22,810(48,055)\end{array}$} & \multirow{2}{*}{$\begin{array}{l}\text { Not Specified } \\
(104) \\
13,386(34,795)\end{array}$} \\
\hline & mean (stdev) & & & & \\
\hline$\left(\mathrm{m}^{2}\right)$ & $\max$ & $1,725,186$ & 943,126 & 357,860 & 228,221 \\
\hline & $\min$ & 674 & 402 & 523 & 1,237 \\
\hline \multirow{3}{*}{$\begin{array}{l}P \\
(\mathrm{~m})\end{array}$} & mean (stdev) & $769.2(949.1)$ & $588.6(600.2)$ & $526.0(513.8)$ & $378.8(324.4)$ \\
\hline & $\max$ & $9,019.8$ & $5,855.0$ & 3449.1 & 1918.3 \\
\hline & $\min$ & 123.2 & 92.3 & 92.0 & 143.7 \\
\hline \multirow{3}{*}{$\begin{array}{l}L \\
(\mathrm{~m})\end{array}$} & mean (stdev) & $291.3(366.3)$ & $216.3(227.6)$ & $196.0(191.3)$ & $143.7(120.8)$ \\
\hline & $\max$ & $3,556.3$ & $2,101.0$ & 1403.0 & 713.9 \\
\hline & $\min$ & 46.3 & 34.4 & 37.9 & 53.1 \\
\hline \multirow{3}{*}{$\begin{array}{l}W \\
(\mathrm{~m})\end{array}$} & mean (stdev) & $137.1(144.0)$ & $111.9(98.7)$ & $102.7(85.5)$ & $80.7(73.8)$ \\
\hline & $\max$ & $1,247.6$ & 721.7 & 476.6 & 429.6 \\
\hline & $\min$ & 20.0 & 18.7 & 18.0 & 26.4 \\
\hline \multirow{3}{*}{$\begin{array}{l}W / L \\
(-)\end{array}$} & mean (stdev) & $0.536(0.167)$ & $0.547(0.163)$ & $0.561(0.147)$ & $0.571(0.154)$ \\
\hline & $\max$ & 0.892 & 0.888 & 0.898 & 0.896 \\
\hline & $\min$ & 0.174 & 0.149 & 0.186 & 0.276 \\
\hline \multirow{3}{*}{$\begin{array}{l}P / A \\
\left(\mathrm{~m}^{-1}\right)\end{array}$} & mean (stdev) & $0.054(0.035)$ & $0.065(0.042)$ & $0.060(0.036)$ & $0.072(0.032)$ \\
\hline & $\max$ & 0.199 & 0.229 & 0.211 & 0.145 \\
\hline & $\min$ & 0.003 & 0.006 & 0.009 & 0.008 \\
\hline \multirow{3}{*}{$\begin{array}{l}A /(L \times W) \\
(-)\end{array}$} & mean (stdev) & $0.664(0.081)$ & $0.636(0.094)$ & $0.667(0.083)$ & $0.652(0.089)$ \\
\hline & $\max$ & 0.842 & 0.842 & 0.852 & 0.809 \\
\hline & $\min$ & 0.331 & 0.340 & 0.437 & 0.397 \\
\hline \multirow{3}{*}{$\begin{array}{l}2(\pi A)^{0.5} / P \\
(-)\end{array}$} & mean (stdev) & $0.783(0.114)$ & $0.760(0.129)$ & $0.807(0.114)$ & $0.808(0.099)$ \\
\hline & $\max$ & 0.956 & 0.964 & 0.965 & 0.975 \\
\hline & $\min$ & 0.315 & 0.340 & 0.432 & 0.490 \\
\hline
\end{tabular}


Table 4 Statistical test of difference between variances ( $F$ test) and means ( $t$ test) of geometric characteristics of bedrock- and moraine-dammed lakes (all lakes, i.e. 281 bedrock- and 315 moraine-dammed lakes).

\begin{tabular}{|c|c|c|c|c|c|c|c|c|}
\hline Test & $A$ & $P$ & $L$ & $W$ & $W / L$ & $P / A$ & $A /(L \times W)$ & $2(\pi A)^{0.5} / P$ \\
\hline$F$ & 4.654 & 2.500 & 2.591 & 2.130 & 1.042 & 1.437 & 1.370 & 1.282 \\
\hline$F$ critical & 1.210 & 1.210 & 1.210 & 1.210 & 1.209 & 1.209 & 1.209 & 1.209 \\
\hline$p$ & $<0.001$ & $<0.001$ & $<0.001$ & $<0.001$ & 0.362 & $<0.001$ & $<0.01$ & $<0.05$ \\
\hline$t$ & 2.703 & 2.819 & 3.050 & 2.530 & 0.806 & 3.350 & 3.854 & 2.330 \\
\hline$t$ critical & 1.965 & 1.964 & 1.964 & 1.964 & 1.964 & 1.964 & 1.964 & 1.964 \\
\hline$p$ & $<0.01$ & $<0.01$ & $<0.01$ & $<0.05$ & 0.421 & $<0.001$ & $<0.001$ & $<0.05$ \\
\hline
\end{tabular}

Table 5 Statistical test of difference between variances ( $F$ test) and means ( $t$ test) of geometric characteristics of bedrock- and moraine-dammed lakes (lakes > 50,000 $\mathrm{m}^{2}$, i.e. 38 bedrock- and 63 moraine-dammed lakes).

\begin{tabular}{lllll|l|l|l|l|} 
Test & $A$ & $P$ & $L$ & $W$ & $W / L$ & $P / A$ & $A /(L \times W)$ & $2(\pi A)^{0.5} / P$ \\
\hline$F$ & 3.428 & 1.874 & 1.815 & 2.555 & 1.450 & 1.742 & 1.786 & 1.355 \\
$F$ critical & 1.658 & 1.658 & 1.658 & 1.658 & 1.658 & 1.658 & 1.658 & 1.658 \\
\hline$p$ & $<0.05$ & $<0.05$ & $<0.05$ & $<0.01$ & 0.113 & $<0.05$ & $<0.05$ & 0.161 \\
$t$ & 1.900 & 2.131 & 2.206 & 1.625 & 1.677 & 1.023 & 0.081 & 1.224 \\
$t$ critical & 1.984 & 1.985 & 1.985 & 1.984 & 1.984 & 1.986 & 1.986 & 1.984 \\
$p$ & 0.060 & $<0.05$ & $<0.05$ & 0.107 & 0.097 & 0.309 & 0.936 & 0.224
\end{tabular}
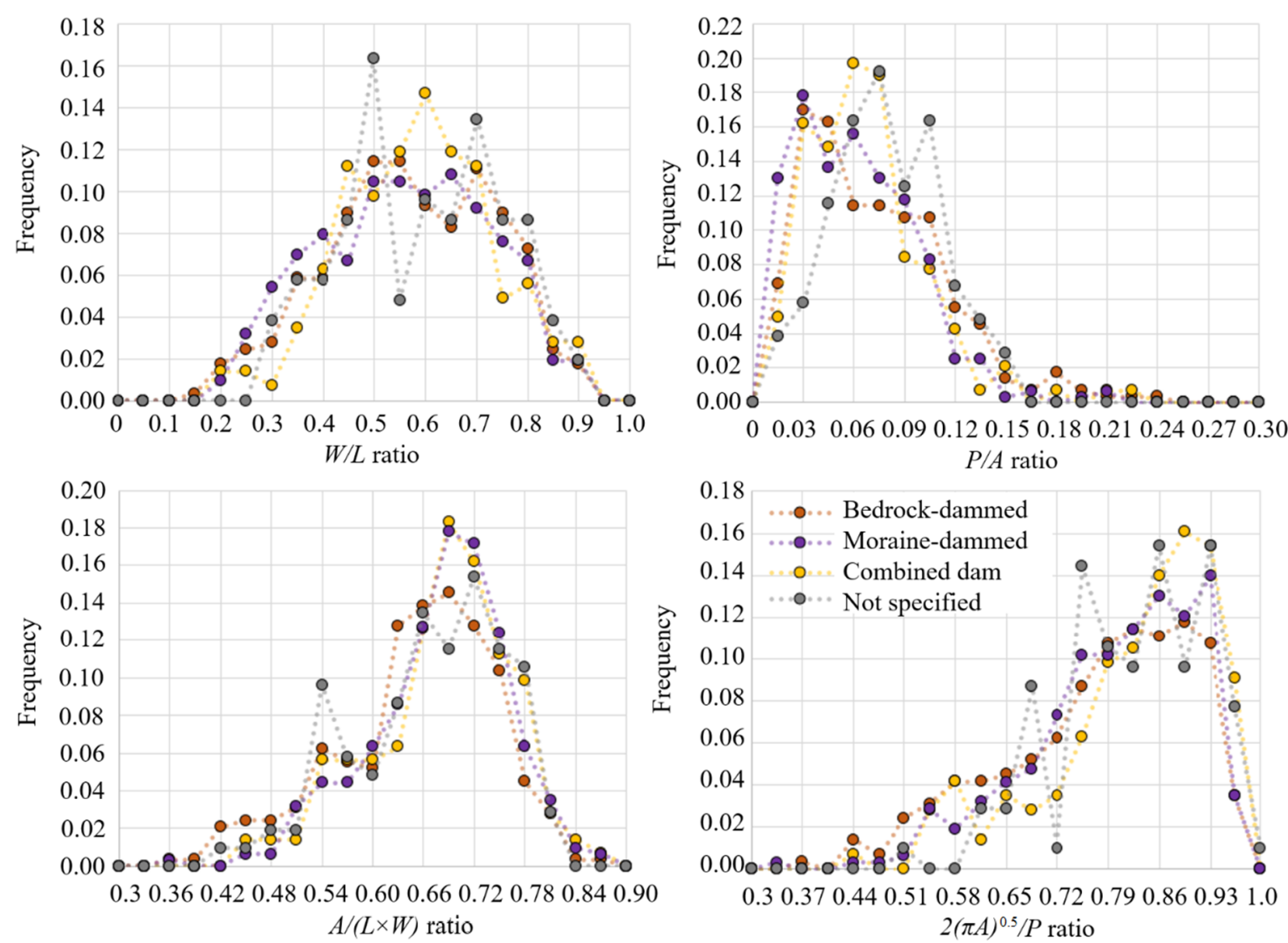

Fig.2 Histograms (relative frequencies) of four geometric ratios for different lake dam types.

suggest that these have similar histograms of values when individual geometric ratios are plotted (see Fig.2). Pearson correlation coefficient between each pair of different lake dam types show strong positive correlation (>0.8) for the value frequencies (histograms) of all geometric ratios, indicating similar frequency distribution along the spectra. The likelihood of certain lake dam type is, therefore, quite similar for different values of individual ratios and our data suggest that these ratios, thus, can't be employed to approximate the lake dam type.

Considering only the lakes with $\mathrm{A}>50,000 \mathrm{~m}^{2}$ 

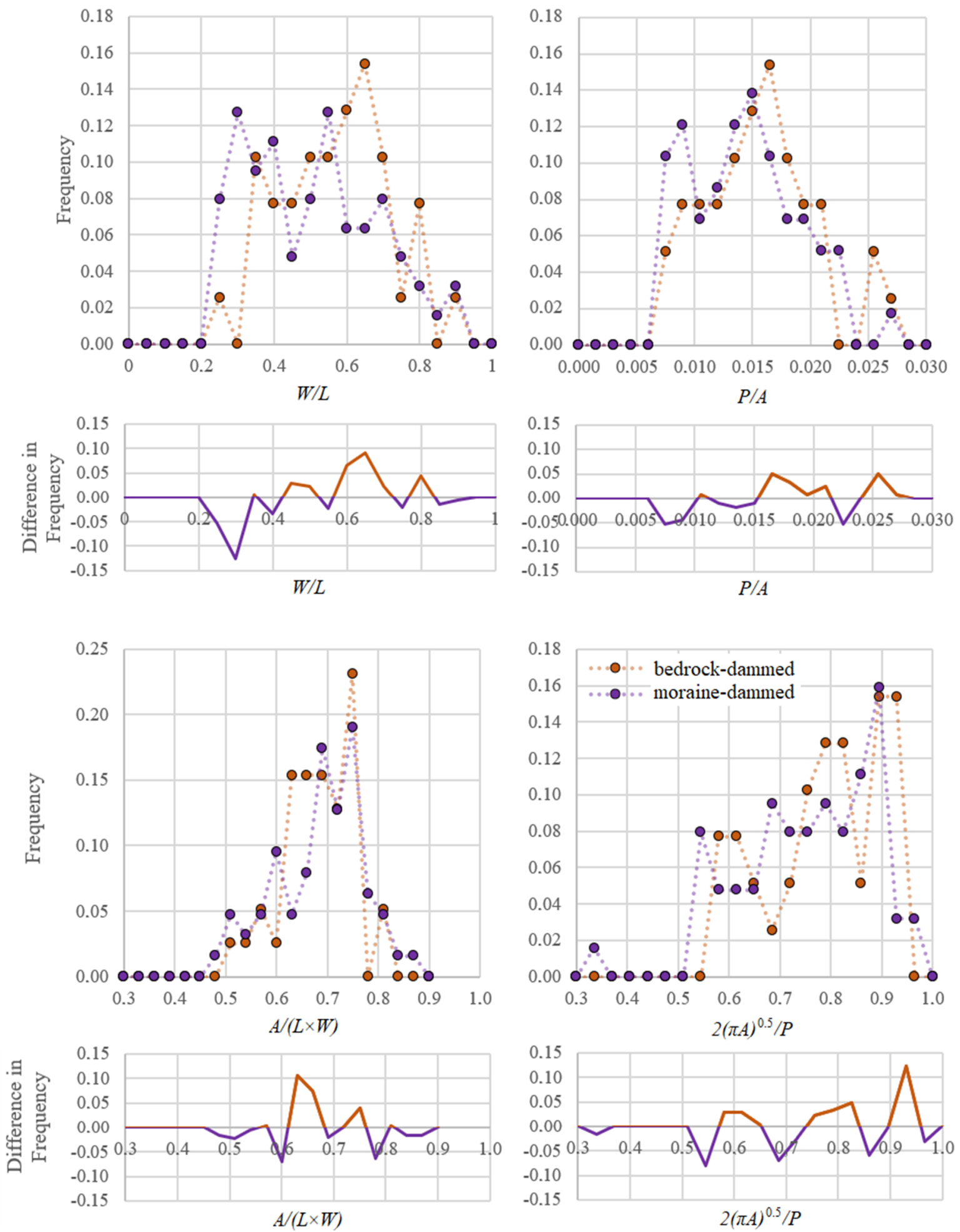

Fig. 3 Histograms of four geometric ratios for large $\left(>50,000 \mathrm{~m}^{2}\right)$ bedrock- and moraine-dammed lakes.

and two dominant lake dam types ( 38 bedrock- and 63 moraine-dammed lakes), resulting histograms (see Fig.3) have similar shape to the histograms for the whole dataset (compare to Fig.2). More visible differences in histograms of individual lake dam types are, however, observed for the subset of large lakes 
(see Fig.3). An example is increased share of morainedammed lakes with the $W / L$ ratio 0.2 - 0.3 . This observation can be explained by the location of large moraine-dammed lakes in the relatively flat main valleys, thus having prolonged shape and comparably lower $W / L$ ratios. Similarly, increased share of bedrock-dammed lakes is observed for the highest values ( $>0.9$ ) of the $2(\pi A)^{0.5} / P$ ratio, indicating almost circular shape of some of the large bedrock-dammed lakes. These are thought to be a circle-shaped lakes occupying glacier-free cirque depressions. These findings are also supported by the histograms of $P / A$ ratio, suggesting increased occurrence of large moraine-dammed lakes with lower $P / A$ ratio (0.005o.010) and increased occurrence of large bedrockdammed lakes with higher $P / A$ ratio (>0.025). Increased share of moraine-dammed lakes is observed with higher $A /(L \times W)$ ratio.

If the likelihood of specific lake dam type (moraine- or bedrock-dammed) is approximated by relative frequency within a specific bin, we can summarise our finding as follows: (i) there is a $92.9 \%$ likelihood that the lake is moraine-dammed if $W / L$ ratio is $0.2-0.3$; (ii) there is $67.2 \%$ likelihood that the lake is moraine-dammed if the $P / A$ ratio is $<0.02$ and $79.6 \%$ likelihood that the lake is moraine-dammed if the $P / A$ ratio is < 0.01 ; (iii) there is $64.2 \%$ likelihood that the lake is moraine-dammed if the $A /(L \times W)$ ratio is 0.70 or large and $77.8 \%$ likelihood that the lake is moraine-dammed if the $A /(L \times W)$ ratio is > 0.73; (iv) there is a $60.0 \%$ likelihood that the lake is bedrockdammed if the $2(\pi A)^{0.5} / P$ ratio is 0.9 or larger. Clearly, likelihoods of moraine-dammed lakes are higher (and the differences in relative frequencies are more amplified), because there are 63 large morainecompared to 38 large bedrock-dammed lakes in the dataset. However, only little difference in relative frequencies $(<0.05)$ is observed for most of the bins (Fig.3) and possibly limited number of lakes also has to be considered when approximating likelihood from relative frequencies.

\subsection{Concluding remarks}

Despite some promising observations, our general findings are not sufficient for introducing robust and consistent methodology for approximating lake dam type based on the lake polygon geometry only. Therefore, we report a negative result of our experiment, suggesting that manual assignment of lake dam type is still necessary to be done, based on the visual interpretation of high-resolution images and - optimally - field validation. As for the future research directions, we opine that multi-criteria analysis of lake geometries with other automatically derivable information (e.g. $3 \mathrm{D}$ morphological characteristics of lake dam and lake surrounding, employment of multispectral data, utilizing supervised classification algorithms, etc.) could lead to better results and deserves further attention in recent efforts in automatization of lake detection and classification procedure (e.g. Zhang et al. 2019; Wangchuk and Bolch 2020).

\section{Acknowledgments}

We thank three anonymous reviewers for their comments and suggestions which helped to improve this study. The authors acknowledge the financial support by the University of Graz. This work was partly supported by the Ministry of Education, Youth and Sports of the Czech Republic within the National Sustainability Programme I (NPU I), grant number LO1415 and Supporting perspective human resources Programme of the Czech Academy of Sciences, project "Dynamics and spatiotemporal patterns of glacial lakes evolution and their implications for risk management and adaptation in recently deglaciated areas" awarded to AE.

Author Contributions: Emmer designed the study, developed methodological framework and prepared lake inventory. Cuř́n run GIS analysis. Both authors contributed to the writing process and approved the final version of the text.

Electronic supplementary material: Supplementary materials (Appendixes 1,2) are available in the online version of this article at https://doi.org/10.1007/s11629-020-6003-9

Open Access This article is distributed under the terms of the Creative Commons Attribution 4.0 International License (http://creativecommons. org/licenses/by/4.0/), which permits unrestricted use, distribution, and reproduction in any medium, provided you give appropriate credit to the original author(s) and the source, provide a link to the Creative Commons license, and indicate if changes were made. 


\section{References}

Aggarwal S, Rai S, Thakur PK, Emmer A (2017) Inventory and recently increasing GLOF susceptibility of glacial lakes in Sikkim, Eastern Himalaya. Geomorphology 30(295): 39-54. https://doi.org/10.1016/j.geomorph.2017.06.014

Allen SK, Zhang G, Wang W, Yao T, Bolch T (2019) Potentially dangerous glacial lakes across the Tibetan Plateau revealed using a large-scale automated assessment approach. Sci Bull 64(7): 435-445.

https://doi.org/10.1016/j.scib.2019.03.011

ArcGIS Pro manual (2019) Available online: https://pro.arcgis.com/en/pro-app/tool-reference/datamanagement/minimum-bounding-geometry.htm (accessed in spring 2019)

Carrivick JL, Tweed FS (2016) A global assessment of the societal impacts of glacier outburst floods. Glob Planet Change 144: 1-16. https://doi.org/10.1016/j.gloplacha.2016.07.001

Chen W, Fukui H, Doko T, Gu X (2012) Improvement of glacial lakes detection under shadow environment using ASTER data in Himalayas, Nepal. Chin Geogr Sci 23: 216-226. https://doi.org/10.1007/s11769-012-0584-3

Clague JJ, Evans SG (2000) A review of catastrophic drainage of moraine-dammed lakes in British Columbia. Quat Sci Rev 19: $1763-1783$.

https://doi.org/10.1016/So277-3791(oo)ooo9o-1

Cook K, Andermann C, Gimbert F, Raj Adhikari B, Hovius N (2018) Glacial lake outburst floods as drivers of fluvial erosion in the Himalaya. Science 362(6410): 53-57 https://doi.org/10.1126/science.aat4981

Emmer A (2017) Geomorphologically effective floods from moraine-dammed lakes in the Cordillera Blanca, Peru. Quat Sci Rev 177: 220-234.

https://doi.org/10.1016/j.quascirev.2017.10.028

Emmer A (2018) GLOFs in the WOS: bibliometrics, geographies and global trends of research on glacial lake outburst floods (Web of Science, 1979-2016). Nat Hazards Earth Syst Sci 18: 813-827. https://doi.org/10.5194/nhess-18-813-2018

Emmer A, Vilímek V (2013) Review article: Lake and breach hazard assessment for moraine-dammed lakes: an example from the Cordillera Blanca (Peru). Nat Hazards Earth Syst Sci 13: 1551-1565. https://doi.org/10.5194/nhess-13-1551-2013

Emmer A, Klimeš J, Mergili M, et al. (2016) 882 lakes of the Cordillera Blanca: an inventory, classification, evolution and assessment of susceptibility to outburst floods. Catena 147: 269-279. https://doi.org/10.1016/j.catena.2016.07.032

Emmer A, Harrison S, Mergili M, et al. (2020) 70 years of lake evolution and glacial lake outburst floods in the Cordillera Blanca (Peru) and implications for the future. Geomorphology 365: 107178.

https://doi.org/10.1016/j.geomorph.2020.107178
GAPHAZ (2017) Assessment of Glacier and Permafrost Hazards in Mountain Regions - Technical Guidance Document. Allen S, Frey H, Huggel C, et al. (Eds.), Zurich, Switzerland / Lima, Peru, $72 \mathrm{pp}$.

Google Inc. (2015) Google Earth Pro, v.7.1.5.1557.

Harrison S, Kargel JS, Huggel C, et al. (2018) Climate change and the global pattern of moraine-dammed glacial lake outburst floods. Cryosphere 12: 1195-1209.

https://doi.org/10.5194/tc-12-1195-2018

Huggel C, Haeberli W, Kääb A, et al. (2004) An assessment procedure for glacial hazards in the Swiss Alps. Can Geotech J 41(6): 1068-1083.

https://doi.org/10.1139/To4-053

Kougkoulos I, Cook SJ, Jomelli V, et al. (2018) Use of multicriteria decision analysis to identify potentially dangerous glacial lakes. Sci Total Environ 621: 1453-1466. https://doi.org/10.1016/j.scitotenv.2017.10.083

Li J, Sheng Y (2012) An automated scheme for glacial lake dynamics mapping using Landsat imagery and digital elevation models: a case study in the Himalayas. Int J Remote Sens 33: 5194-5213.

https://doi.org/10.1080/01431161.2012.657370

Mergili M, Schneider JF (2011) Regional-scale analysis of lake outburst hazards in the southwestern Pamir, Tajikistan, based on remote sensing and GIS. Nat Hazards Earth Syst Sci 11: 1447-1462.

https://doi.org/10.5194/nhess-11-1447-2011

Shugar D, Burr A, Haritashya UK, et al. (2020) Rapid worldwide growth of glacial lakes since 1990. Nat Clim Chang 10: 939945 . https://doi.org/10.1038/s41558-020-0855-4

Veh G, Korup O, Roessner S, Walz A (2018) Detecting Himalayan glacial lake outburst floods from Landsat time series. Remote Sens Environ 207: 84-97. https://doi.org/10.1016/j.rse.2017.12.025

Veh G, Korup O, von Specht S, et al. (2019) Unchanged frequency of moraine-dammed glacial lake outburst floods in the Himalaya. Nat Clim Chang 9: 379-383. https://doi.org/10.1038/s41558-019-0437-5

Wangchuk S, Bolch T (2020) Mapping of glacial lakes using Sentinel-1 and Sentinel-2 data and a random forest classifier: Strengths and challenges. Sci Remote Sens 2: 100008. https://doi.org/10.1016/j.srs.2020.100008

Yao X, Liu S, Han L, et al. (2018) Definition and classification system of glacial lake for inventory and hazards study. $J$ Geogr Sci 28: 193-205.

https://doi.org/10.1007/s11442-018-1467-z

Zhang M, Chen F, Tian B, Liang D (2019) Using a PhaseCongruency-Based Detector for glacial lake segmentation in High-Temporal Resolution Sentinel-1A/1B Data. IEEE J Sel Top Appl Earth Observ Remote Sens 12(8): 2771-2780. https://doi.org/10.1109/JSTARS.2019.2900442 